\title{
Social media and mobile communications adoption patterns of South African civil society organisations
}

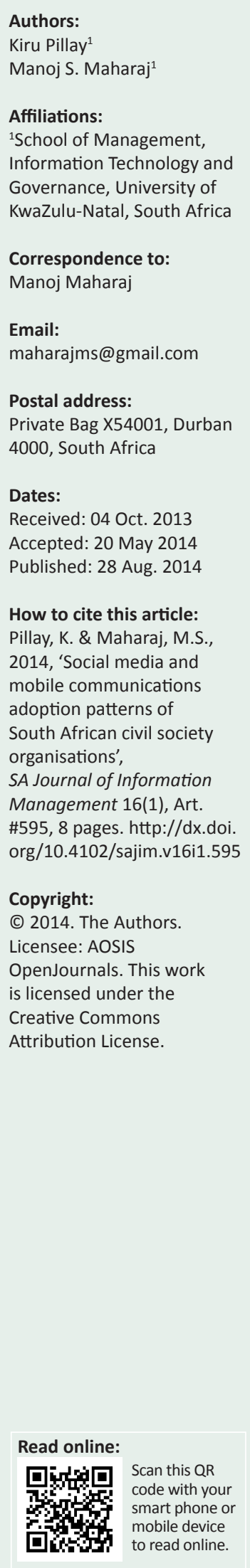

Background: The resurgence of civil society has largely been attributed to the sector's ability to exploit new interactive technologies and its ability to adapt its communication and mobilisation strategies.

Objectives: This study focuses on how South African civil society organisations (CSOs) deploy Web 2.0 services and technologies for social advocacy and the context of this technology use.

Whilst the literature points to many studies relating to the use of the Internet for advocacy, it also suggests that the role and impact of emerging technologies have not been studied in any detail in CSOs. Such studies have the potential to provide new perspectives to current theoretical frameworks and also to add to the discourse around the use of emerging technologies for advocacy.

Method: A survey of South African CSOs explored the level of knowledge of social media services and revealed which services in particular were being adopted.

Results: The key findings that emerged were that the sector has a low level of knowledge of social media services and an accompanying low level of adoption. These are partly explained by factors such as macro-economic policies and low levels of Internet penetration and ICT readiness.

Conclusion: Further research to determine why certain social media services have been embraced more willingly than others and an analysis of the patterns of adoption to determine any underlying significance or relationships is necessary. An analysis of how CSOs build their advocacy capabilities by appropriating social media and how they thus provide alternate discourses and agendas would be instructive.

\section{Introduction}

The 2011 uprising in the Middle East, which started with the self-immolation of a single protester in Tunisia, has had profound worldwide sociopolitical ramifications. Social upheaval has not been confined to the Arab world, with riots in Greece aimed at government-introduced austerity measures, the Los indignados (The outraged) in Spain, civil unrest in other parts of Europe as the Euro crisis deepened and reached levels of contagion not seen since the Great Depression (Huffington 2011) and the Occupy Movement leading protests against the currency crisis and corporate greed in many of the world's major cities. Much of the success of the protests has been attributed to a young restive population with access to social media tools (Huffington 2011; Zakaria 2011).

Social media has also been successfully embraced by established civil society organisations with Greenpeace, for example, deploying social media services like YouTube and Facebook to successfully target large corporations like Nestle, McDonalds and even social networking giant Facebook itself in various campaigns aimed at changing corporate behaviour (Greenpeace 2006, 2010a, 2010b).

\section{Civil society, technology and Web 2.0}

The collective actions of civil society are a result of communication between different civil society actors, which in turn produce alternative discourses and oppositional debates in the public sphere (Fuchs 2008). These communications have always been achieved by a variety of media including brochures, leaflets and newsletters, all with the intention of gaining access to greater numbers of people within the organisation and in the public domain (Van de Donk et al. 2004).

Towards the end of the 1980s, civil society organisations began adopting computer-mediated communications strategies, with the Internet in particular being used to disseminate information. 
This Internet-enabled activism is situated in the broader context of the revival of participatory politics that took place in the 1960s and 1970s (Chadwick 2009). Whilst these Internet-based technologies provide a platform for communication between like-minded organisations, they also facilitate diverse views, which are necessary to embrace a wider audience (Tandon 2000). It has long been recognised that the Internet and digital communication networks have the ability to circumvent barriers that may exist to collective action; they expand the mobilisation capacity of organisations across cultural and national levels (Hara \& Shachaf 2008): Nugroho and Tampubolon (2008) credit the Internet and other advances in information technology with the current reinvention of the global civil society. The attractiveness of Internet technologies lies in its distributed, decentralised and relatively cheap and easily deployable architecture, which matches the organisational and political logic of global civil society networks (Deibert \& Rohozinski 2008).

The emergence of a new set of interactive technologies, under the umbrella term of Web 2.0 (or social media), has resulted in a significant increase in Internet-driven campaigning (Castells 2009). Civil society now has the ability to advance their agenda through these technologies, to the extent that some commentators contend that the balance of power between governments and their citizens has shifted, largely due to the use of social media (Gapper 2009; Hara \& Shachaf 2008). There are numerous open-standards websites and technologies (also referred to as services) that encapsulate the Web 2.0 concept; the Pew Research Center (2011) describes Web 2.0 as:

an umbrella term that is used to refer to a new era of Webenabled applications that are built around user-generated or user-manipulated content, such as wikis, blogs, podcasts, and social networking sites. (n.p.)

\section{South African civil society}

The history of South African civil society is characterised by two distinct periods. The first dates back to the early 1980s when there was a prodigious growth in civil society rooted in the protests against apartheid. The second phase dates to the post-democracy years from 1994 onwards when civil society, faced with different challenges and also new opportunities, changed fundamentally (Habib 2003). Prior to 1994 the majority of South African civil society organisations (CSOs) shared common cause with the dominant exiled liberation movements; post 1994, with the advent of democracy, civil society began to adopt more 'traditional' civil societytype activities and sought to place citizens' interests on the government's agenda (Ranchod 2007). The new democratic political environment has also resulted in the formation of many new social movements united against government's macro-economic policies, which they believe will further entrench poverty and inequality in South Africa.

\section{Contextualising the research problem}

The resurgence of civil society has been attributed to the sector's ability to exploit new emerging interactive technologies, and its ability to adapt its communication and mobilisation strategies in the emerging technological paradigm (Anheier, Glasius \& Kaldor 2001; Castells 2004). Increased technological innovation has also given rise to distinctly new types of CSOs that can only exist in a digitally connected world. Ushahidi (2011) and Avaaz (2011) for example have embraced technology as the cornerstone of their strategy, and Garrett (2006) contends that they will gradually eclipse traditional CSOs. Traditional CSOs are increasingly considering how the structure, culture and operations of their organisations need to embrace the new technological paradigm.

South African civil society has been well researched in the recent past (Freedom House 2011; Habib 2003; Ranchod 2007) and research into the adoption of information and communication technologies (ICTs) in South African CSOs has also been well represented. In particular, two surveys, one in 2007 and the other in 2009, on the adoption of ICTs and the Internet by civil society were undertaken by a nongovernmental organisation, the Southern African NGO Network (SANGONeT) in conjunction with the Internet research house World Wide Worx (2009). Whilst there has been research into the adoption of social media in international CSOs (MobileActive 2010; NTEN 2010, 2011a, $2011 \mathrm{~b}$ ), no published research into the adoption of social media in South African civil society has been undertaken to date. This study explores the extent to which South African CSOs deploy social media services and in particular identifies which services are being appropriated.

\section{Research methodology}

A survey, designed to evaluate the levels of knowledge and adoption of Web 2.0 services and targeting South African civil society organisations, was conducted between May 2011 and June 2011. The results of the survey painted a picture of the levels of knowledge and extent of adoption of Web 2.0 services across South African CSOs. The survey targeted South African CSOs whose details are stored in a database of South African CSOs maintained by the nongovernment organisation SANGONeT (2011). At the time of the survey 1712 organisations were eligible for this research (i.e. operational CSOs with an Internet presence and a valid email address). The contact persons listed on the organisations' websites were targeted by the survey and they were requested to either complete the survey or forward it to the relevant person in the organisation who could provide the requested information. At the end of the survey 122 responses were received and analysed, which represented $7 \%$ of the target population.

The theoretical framework underpinning this study is the diffusion of innovations (Rogers 2003), the use of which in the study of technology adoption has been established in research, in particular by Nugroho's (2007) study into the effects of Internet adoption in Indonesian civil society. Diffusion of Innovations provides a rigorous approach to theories of social change (Wejnert 2002) and also 
provides a theoretical framework for the identification and understanding of the constructs that impact the adoption of Web 2.0 in CSOs.

\section{Analysis of results: Web 2.0 knowledge in South African civil society organisations}

Figure 1 depicts the levels of knowledge regarding the use of Web 2.0 services as reported by respondents from South African CSOs. The original responses to this question were on a scale of one to five, with one representing 'not at all knowledgeable' and five meaning 'very knowledgeable'. The responses received were then grouped as follows: ones and twos were recorded under the heading 'a little knowledgeable'; threes were recorded as 'somewhat knowledgeable'; fours and fives were recorded as 'fairly knowledgeable'.

In response to the question on the levels of knowledge with regard to specific Web 2.0 services, respondents indicated 'fairly knowledgeable' for the following services: 55.4\% for social networks, $43.3 \%$ for photos and multimedia sharing and $51.2 \%$ for messenger applications. The respondents indicated 'a little knowledge' for the following services: $73.6 \%$ for both social bookmarking and podcasts, 53.7\% for both blogging and microblogging and $83.5 \%$ for data mashups.

\section{Web 2.0 adoption in South African civil society}

Figure 2 illustrates the extent and timelines of individual social media services adoption, with respondents reporting their organisations having adopted social media services as follows ${ }^{1}$ :

- Social networks (82.4\%)

- Photos and multimedia sharing (58.8\%)

- Messenger applications (63\%)

- Creating and maintaining of blogs (44.9\%)

- Microblogging (43.7\%)

- Wikis $(42.4 \%)$

- RSS feeds (44.6\%)

Respondents reported the following services as having not been adopted within their organisations: social bookmarking $(76.5 \%)$, downloading and the publishing of podcasts $(60.8 \%$ and $72 \%$ respectively) and data mashups (71.2\%). Respondents reported almost evenly on their organisations either having adopted blogging services (50\%) or not having adopted this service $(44.9 \%)$.

Table 1 illustrates the relationship between the adoption of social media services and the levels of knowledge regarding these services. Generally there is a strong correlation between knowledge and adoption rates of services. Only one service, the monitoring of the blogosphere, does not reveal a strong relationship, with $46.2 \%$ of respondents indicating being fairly

1.Adoption of services is reported by aggregating the responses from the following response categories: 'approximately three months ago', 'approximately six months ago' and 'approximately one year or more ago'. knowledgeable but with only $19.3 \%$ of respondents indicating that their organisations have adopted the service.

Rogers's (2003) diffusion of innovation framework, and specifically the attributes of relative advantage, compatibility, complexity, trialability and observability, can be used to begin to understand the emerging adoption patterns exhibited by South African CSOs. Compatibility for example, which is based on an organisation's need to adopt, explains why with $80 \%$ of online users in South Africa having a Facebook account (World Wide Worx 2011), it becomes incumbent on CSOs to adopt social networking in order to exploit this channel of communication and to potentially reach a larger audience.

Complexity - or the degree of difficulty in understanding and ultimately using an innovation - provides a possible explanation for the low adoption rates of data mashups (11\%). Mashups are complex in that they have to aggregate various different types of data sources (e.g. databases and legacy systems). Furthermore, mashups are generally programmed by developers or have to be developed using a mashup development tool. Additionally, emerging technologies change constantly, which in turn means that CSOs have to engage with these technologies in an ongoing process of discovery and learning.

In a survey conducted by the Nonprofit Technology Network (NTEN 2010), it emerged that CSOs lack the trained staff required to improve the use of social networks, with $74.1 \%$ of respondents indicating a need to know 'which tools are useful for what' and $44.4 \%$ indicating a need for training in how these tools work.

Trialability is the ability to experiment with an innovation prior to any decision to adopt or reject it. Social networking and photos and multimedia sharing were cited by $82.4 \%$ and

Table 1: Adoption of Web 2.0 services reflect civil society organisations knowledge of services.

\begin{tabular}{lll}
\hline Social media service & $\begin{array}{l}\text { Cumulative } \\
\text { adoption (\%) }\end{array}$ & $\begin{array}{l}\text { Fairly and somewhat } \\
\text { knowledgeable (\%) }\end{array}$ \\
\hline $\begin{array}{l}\text { Social networks } \\
\text { (e.g. Facebook, MySpace) }\end{array}$ & 82.4 & 81 \\
$\begin{array}{l}\text { Social bookmarking } \\
\text { (e.g. del.icio.us, Social Marker) }\end{array}$ & 16 & 26.5 \\
$\begin{array}{l}\text { Downloading of podcasts } \\
\text { (e.g. Juice, iTunes) }\end{array}$ & 29.2 & 26.4 \\
$\begin{array}{l}\text { Publishing of podcasts } \\
\text { (e.g. Podcaster, PodProducer) }\end{array}$ & 17.8 & 26.4 \\
$\begin{array}{l}\text { Photos and multimedia sharing } \\
\text { (e.g. Flickr, YouTube) }\end{array}$ & 58.8 & 68.3 \\
$\begin{array}{l}\text { Creating and maintaining own blogs } \\
\text { (e.g. Blogger, WordPress) }\end{array}$ & 44.9 & 46.2 \\
$\begin{array}{l}\text { Monitoring the blogosphere } \\
\text { (e.g. Technorati) }\end{array}$ & 19.3 & 46.2 \\
$\begin{array}{l}\text { Microblogging } \\
\text { (e.g. Twitter, Tumblr) }\end{array}$ & 43.7 & 46.3 \\
$\begin{array}{l}\text { Wikis } \\
\text { (e.g. Wikipedia) }\end{array}$ & 42.4 & 59.5 \\
$\begin{array}{l}\text { RSS feeds } \\
\text { (e.g. FeedReader, Google Reader) }\end{array}$ & 44.6 & 52.1 \\
$\begin{array}{l}\text { Data mashups } \\
\text { (e.g. Ushahidi) }\end{array}$ & 11 & 16.6 \\
$\begin{array}{l}\text { Messenger applications } \\
\text { (e.g. MXit, Skype) }\end{array}$ & 63 & 66.9 \\
\hline
\end{tabular}




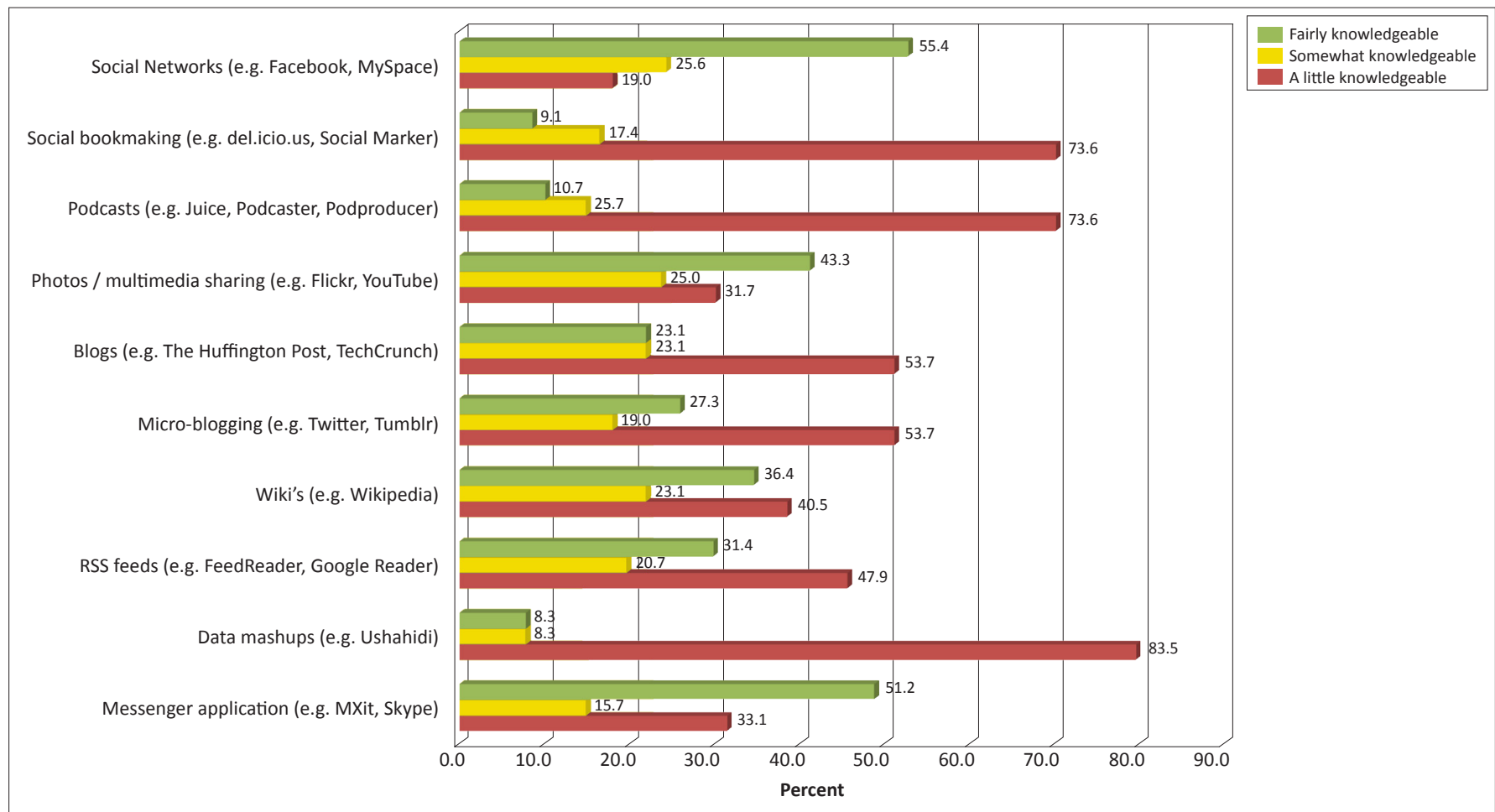

FIGURE 1: Knowledge of social media services in South African civil society organisations.

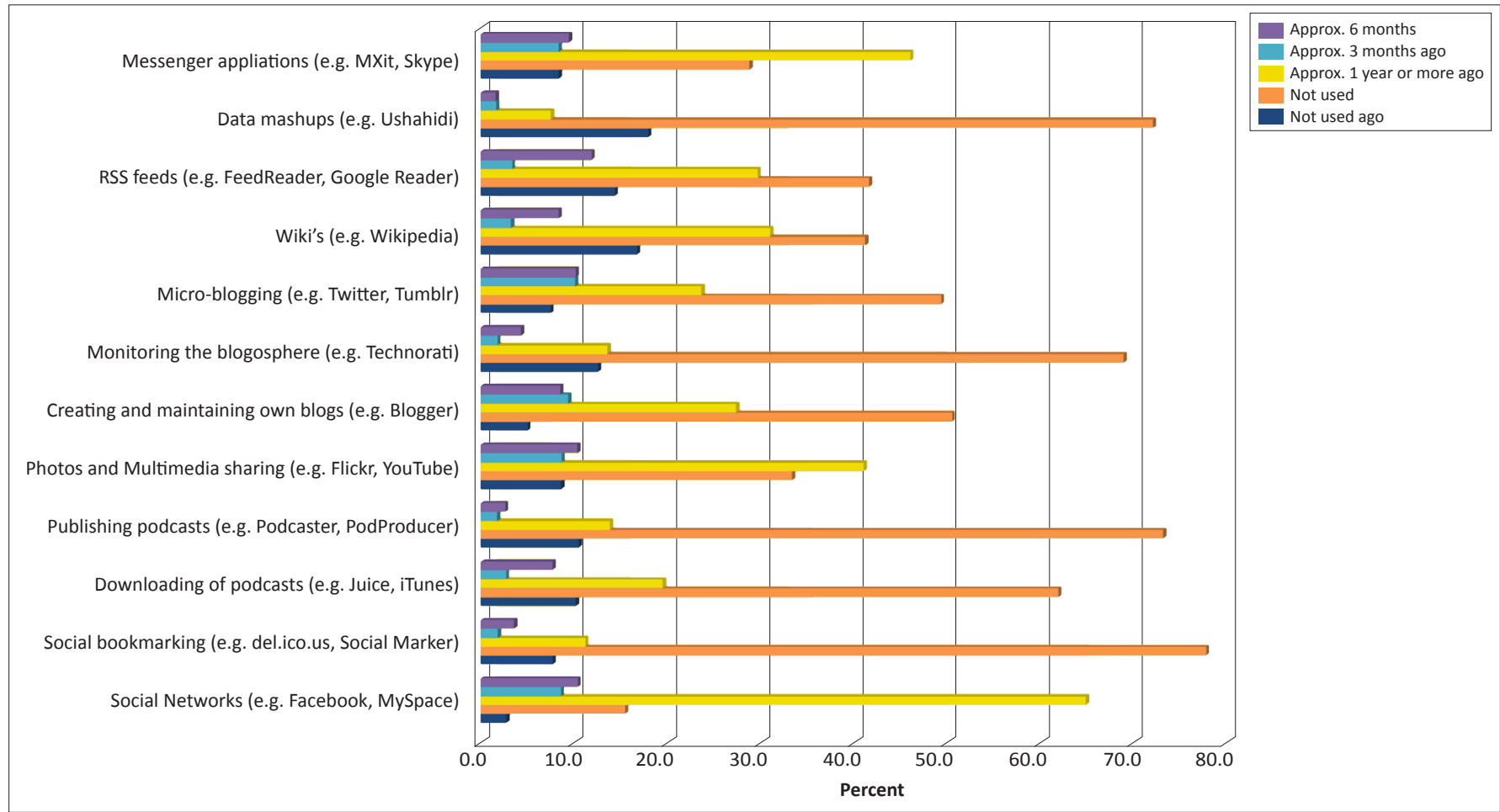

FIGURE 2: Social media service adoption in South African civil society organisations.

$58.8 \%$ of respondents respectively as having been adopted by their organisations. Both these services can be discontinued fairly easily: Facebook in particular has evolved some fairly mature and well-defined steps for users wishing to discontinue their service.

The penetration rate for cellular phones in South Africa is fast approaching $100 \%$ of the adult population; this may be one possible reason why messenger applications and social networks are cited as having being adopted by a large percentage of CSOs (63\% and $82.4 \%$ respectively). In a survey conducted by the European Network and Information Security Agency (ENISA), it was found that users who access Facebook via their mobile devices were approximately $50 \%$ more active on their Facebook accounts than nonmobile users (ENISA 2010), illustrating an increasing level 
of online activity on cellular phones. A study conducted by the University of Cape Town into digital media usage on cellular phones amongst urban youth found that $93 \%$ of youth surveyed access the Internet on their mobile devices (Kreutzer 2009). A report by the United Nations Children's Fund (UNICEF 2011) states that Internet access via the mobile network has already significantly influenced South African society through the wide-scale adoption of mobilebased applications such as MXit.

The use of photographs and imagery has always been an important tool in the arsenal of CSOs; Doyle (2007) states that photographs provide a discourse on 'visual truth' and effectively communicate the reality on the ground. This is supported by the research, which saw $58.8 \%$ of respondents indicating the adoption of photos and multimedia sharing services within their organisations.

\section{Social networking in South Africa civil society organisations}

The impact of social networking sites (not exclusively Facebook) in South African CSOs is depicted in Figure 3. Respondents reported that $37.8 \%$ of organisations have attracted at least 1000 visitors to their social networking sites. The Internet research organisation Socialbakers (2011) estimates that there were approximately 4511220 Facebook users in South Africa as at January 2012, which implies that South African CSOs had managed to attract just $0.02 \%$ of South African Facebook users to their sites. Only 2.5\% of organisations have managed to attract more than 50000 users to their social network sites.

\section{Extent of Web 2.0 use}

Figure 4 depicts the extent of usage of social media amongst South African CSOs as shown by respondents' answers to the survey question: 'Where would you place your organisation with respect to engaging with Web 2.0 social media?' Of the responses received, $21.5 \%$ of respondents reported using Web 2.0 services in almost all aspects of their work. There is an almost equal split between organisations using Web 2.0 in some aspects of their work (35.5\%) and those who use it in only a few aspects of their work (33.1\%). Respondents

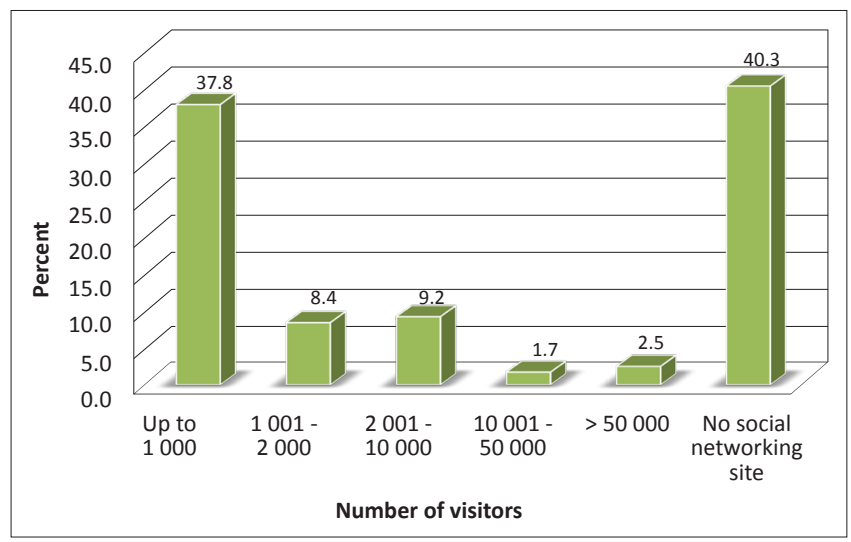

FIGURE 3: Number of visitors to civil society organisations social networking sites. indicated that $10 \%$ of their organisations do not engage with social media in any aspects of their work.

\section{Social media adoption on a mobile platform}

Mobile phones have become woven into the fabric of society; Columbia University's Earth Institute describes mobile phones as 'the single most transformative tool for development' (The Economist 24 September 2009:n.p.). In addition to being a useful tool in itself, mobile technology provides platforms for social media and offers great potential to communication independent of space and time ( $\mathrm{Wu} \&$ Unhelkar 2010). According to ENISA (2010) approximately 65 million people accessed Facebook via their mobile phones in 2009, whilst Facebook reported this number rose to more than 500 million in 2013 (Facebook 2013).

Figure 5 illustrates the cellular phone usage amongst South African CSOs. Whilst the responses were on a scale of one to five with one meaning low usage and five meaning high usage, these categories were aggregated and reported on as follows: ones and twos were recorded as 'less than average', threes were recorded as 'average' and fours and fives were recorded as 'above average'; $66.1 \%$ of respondents rated their organisations' usage of cellular phones as 'above average' for standard usage (i.e. making calls and texting), whilst $47.9 \%$ indicated an 'above average' usage for advanced use (i.e. connecting to the Web, accessing emails, etc.).

\section{Development of a mobile platform}

The development of mobile platforms amongst CSOs is illustrated in Figure 6. With respect to organisational plans to migrate websites and social media services to a mobile platform, respondents reported as follows: $43.8 \%$ reported no organisational plans to migrate, $30.6 \%$ of organisations were reported as currently in the process of developing mobile platforms and $18 \%$ had plans to do so within the next 12 months. Cumulatively, $48.6 \%$ of organisations were reported as either currently in the process of migrating to a mobile platform or planning to migrate in the next 12 months.

A report sponsored by a United Nations foundation and the Vodafone Group Foundation (Kinkade \& Verclas 2008) found that whilst mobile phones were still used most extensively

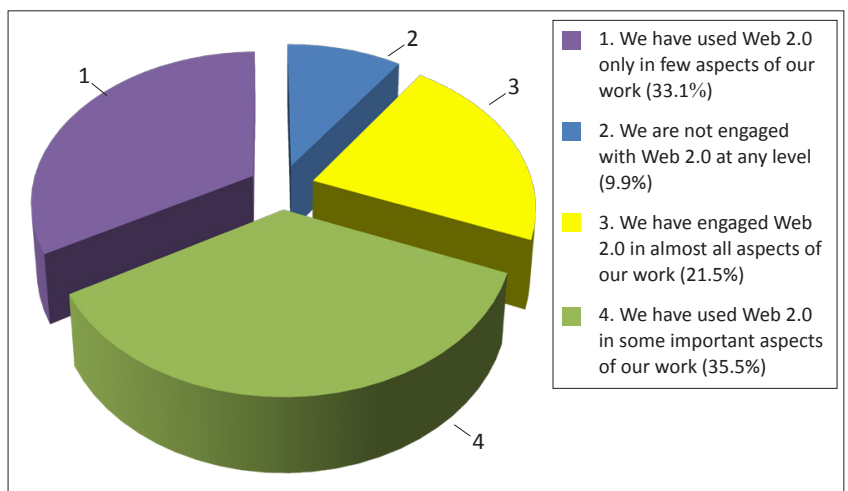

FIGURE 4: Extent of usage of Web 2.0 by South African civil society organisations. 
for making voice calls and for text messaging, many civil society members use their mobile phones in other ways, including: taking and distributing photos and videos (39\%), gathering and transmitting data (28\%) and multimedia messaging (27\%). Additionally, $8 \%$ of respondents reported using their devices for more complex activities like analysing data, whilst 10\% used them for mapping purposes.

\section{Summary: Knowledge and adoption of social media}

What emerges from the data is a sector with an overall low level of knowledge of social media services and an accompanying low level of adoption. The majority of South African CSOs have little knowledge of many social media services; in particular, services like social bookmarking, blogging, microblogging, podcasts and mashups are relatively unknown. Organisations did have knowledge of social networks, photos and multimedia sharing and messenger applications and, not surprisingly, these are the services that have been adopted by South African CSOs (i.e. knowledge mirrors adoption).

\section{Understanding social media usage data in South Africa}

The link between emerging technologies and the wealth of nations, based on accounting models that link these technologies to productivity, has been well established (International Telecommunications Union 2009). Emerging technologies play a prominent role in creating sustainable growth in competitive economies, by helping to modernise these economies and improving living conditions. They also remain crucial not only for enhancing the possibility of innovation and long-term competitiveness of developed countries, but also for encouraging fundamental structural changes to the economy, improving efficiency and also for reducing the digital, economic and social divisions that exist in middle-income countries and developing countries (Greenhill 2011). Dutta, Mia and Geiger (2011) contend that ICTs, particularly social media and mobile phone applications, offer innovative and sophisticated communication channels that enable new types of social relationships.

\section{Social networking adoption versus gross domestic product per Capita}

The Pew Research Centre's Global Attitudes Project (Pew Research Center 2011) states that the number of adults who have a presence on social networking sites is partly related to Internet penetration rates, which in turn is influenced by the wealth of a country as measured by the gross domestic product (GDP). Similarly, the use of one particular social media service (i.e. social networking to explain adoption rates) draws upon arguments advanced by Memmi (2010), which states that social networking is a typical example of social media services.

The scatter graph (Figure 7), using 2012 GDP and social networking usage values that include South Africa,

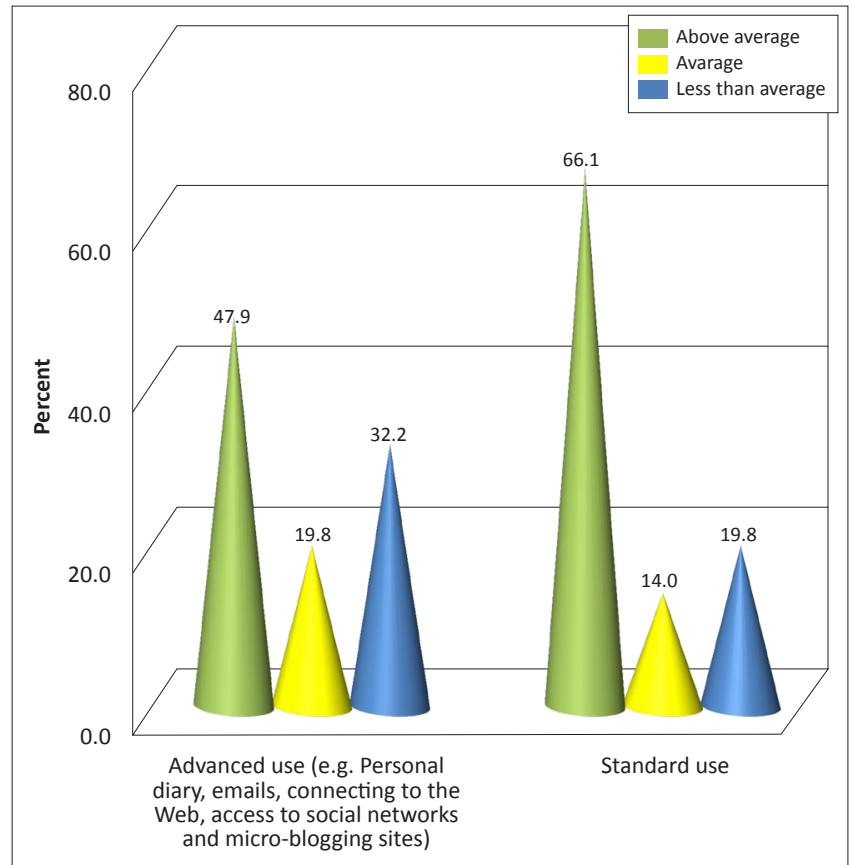

FIGURE 5: Mobile phone usage by South African civil society organisations.

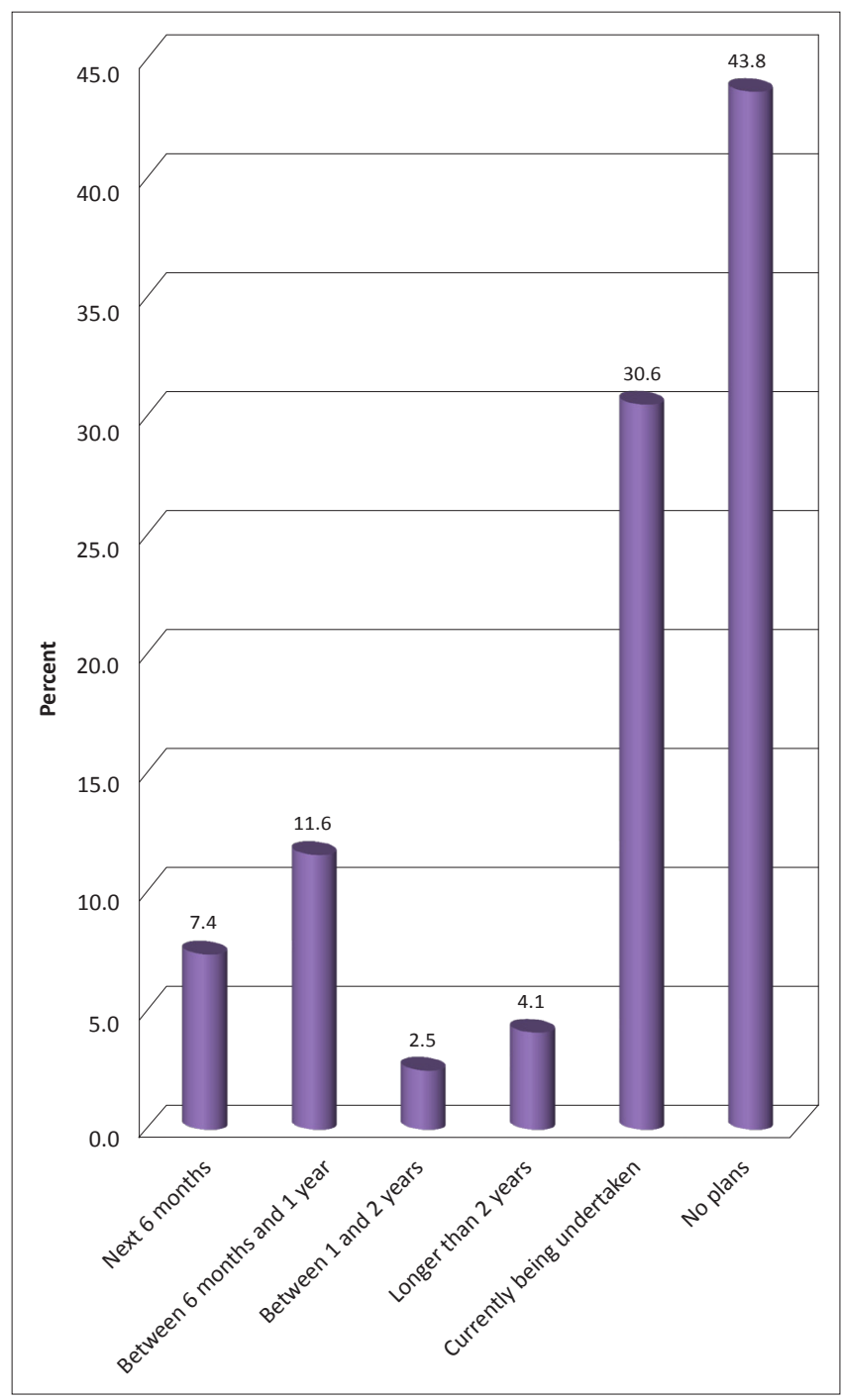

FIGURE 6: When do South African civil society organisations plan to develop a mobile platform? 
illustrates the correlation between a country's GDP and the level of social networking adoption amongst the population. Amongst the countries surveyed, not only does the United States of America (USA) have the highest GDP per capita, but it also has one of the highest adult social networking populations. Pakistan and India in contrast have two of the lowest GDPs per capita and correspondingly they also have the lowest number of social networking users.

If one notes that social networking sites (like Facebook, LinkedIn, etc.) are a typical example of the broader social media umbrella of services (Memmi 2010), then the scatter graph is an indication of social media usage versus GDP (and not just social networking versus GDP). It must also be remembered that whilst there are many niche social networking sites that focus on specific issues or are popular in specific countries (e.g. MySpace for music and entertainment, LinkedIn for professional networking, Orkut in India and Brazil, Skyrock in France, VKontakte in Russia and Cyworld in South Korea, Rigby 2008), Facebook is the most popular social networking platform in South Africa. Plotting South Africa's GDP per capita along the $\mathrm{X}$-axis and Facebook usage along the $\mathrm{Y}$-axis reveals a point on the graph that lies below the regression line, implying that South African social media adoption should actually be higher with respect to its GDP per capita.

\section{Social media adoption and network readiness}

The network readiness index is a widely accepted measure that is used to evaluate an economy's readiness to leverage technological innovation for increased competitiveness; it does this by measuring the degree to which a country's economic infrastructure is conducive to ICT development and diffusion (Dutta \& Mia 2011). South Africa is rated as fairly stable and is placed 70 overall out of a total of 144 countries, with notable strengths in the quality of its market, its regulatory environments and capacity for innovation, amongst others. On a less positive note, individual preparation and uptake of ICT remain very weak, at 113th and 95th respectively (Bilbao-Osorio, Dutta \& Lanvin 2013). This is attributed, in part, to the very high access costs to ICT: South Africa has high subscription rates for monthly residential fixed-line, fixed broadband Internet and mobile cellular connections. Government readiness also remains poor and there has been little success in promoting ICT within government itself.

\section{Social media adoption versus Internet usage}

The Internet and the applications riding on high-speed broadband networks provide a unique and cost-effective way for economies to enhance national competitiveness and to rise above physical and geographic constraints. A report by the Pew Research Centre (2011) indicates that social networking adoption is largely determined by the overall Internet penetration rate of a country. South Africa's Internet penetration is estimated at around $41 \%$ of the population (Broadband Commission 2013). This relatively low Internet

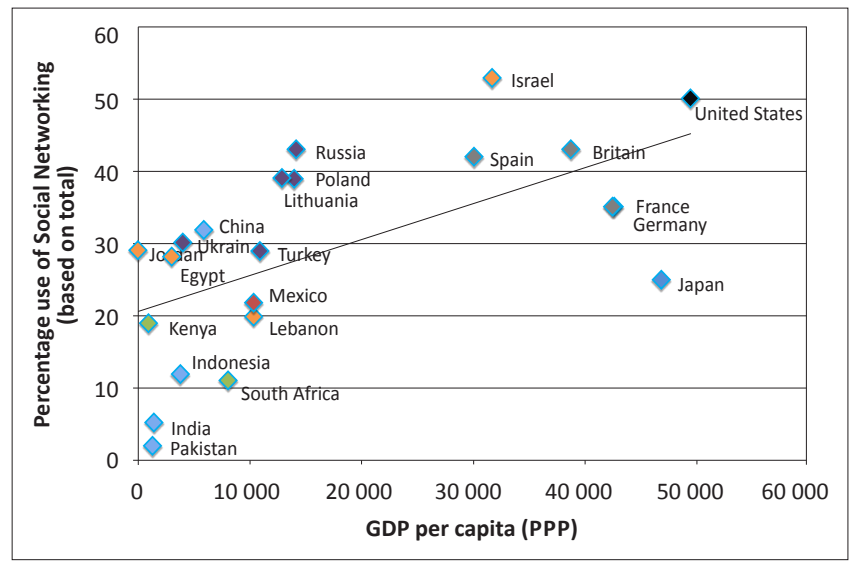

Source: Adapted from Pew Research Center, 2011, Web 2.0, viewed 26 November 2012, from http://www.pewinternet.org/topics/Web-20.aspx (including South Africa with 2012 figures)

FIGURE 7: The GDP per capita (PPP) and use of social networking.

penetration rate is a significant factor in the low adoption rate of social media.

\section{Conclusion}

This study explored the extent to which South African CSOs adopt and deploy social media services and in particular explored the adoption patterns of individual services.

The picture that emerges is that whilst the respondents were strongly positive about the impact of social media on their organisations, there is in fact a low level of adoption of these services. The study reveals a sector slowly awakening to the potential of social media.

Whilst computers and ICTs in general have become integral in South African CSOs the impact of social media is less obvious and many organisations exhibit a low level of knowledge and associated low levels of adoption. It must be cautioned that social media is a bundle of services and not one particular technology or innovation and it is therefore more difficult to qualify the adoption and the emergent patterns of adoption. This study has speculated on why certain social media services are regarded more favourably by CSOs, which is a topic for future research. It must be noted that individual services that have been adopted are generally adopted by a significant majority of organisations. The converse is also true for those services being less well adopted. Low adoption rates can be related to the difficulty of use of the service.

The role of cellular phones as a platform for social media services may also help to explain adoption rates as certain services are ideally suited to the mobile platform and others less so. Instant messaging applications, like MXit for example, are ideally suited to a mobile platform, whilst data mashup services require larger displays to be truly useful. A significant proportion of organisations utilise cellular phones for fairly advanced purposes (like accessing the Internet) as compared to simply using them for making calls and sending and receiving the ubiquitous SMSs. Given the high penetration rate of cellular phones in South Africa 
this is not unexpected. Cellular phones have the potential to become the single most transformative tool for development. Their ability to eliminate the boundaries of time and space is always going to be a vital tool in the arsenal of civil society in order to propagate alternative discourses, stimulate debate and change perceptions and attitudes.

Factors that affect the uptake of social media were also presented and what remains to be seen is what happens going forward both within the sector and in South Africa generally.

\section{Acknowledgements Competing interests}

The authors declare that they have no financial or personal relationship(s) that may have inappropriately influenced them in writing this article.

\section{Authors' contributions}

This article arose out of the PhD research of K.P. (University of KwaZulu-Natal) under the supervision of M.S.M. (University of KwaZulu-Natal).

\section{References}

Anheier, H., Glasius, M. \& Kaldor, M., 2001. 'Introducing global civil society', in H. Anheier, M. Glasius \& M. Kaldor (eds.), Global civil society, pp. 3-22, Oxford University Press, Oxford.

Avaaz, 2011, The world in action, viewed 10 September 2013, from http://www.avaaz. org/en/about.php

Bilbao-Osorio, B., Dutta, S. \& Lanvin, B., 2013, The global information technology report 2013: Growth and Jobs in a hyperconnected world, World Economic Forum, Geneva, Switzerland.

Broadband Commission, 2013, The state of broadband 2013: Universalizing broadband, Author, Geneva, Switzerland.

Castells, M., 2004, The information age: Economy, society and culture, vol. 2, Blackwell Publishing, New York.

Castells, M., 2009, Communication power, Oxford University Press, Oxford.

Chadwick, A., 2009, 'Web 2.0: New challenges for the study of e-democracy in an era of informational exuberance', I/S: A Journal of Law and Policy for the Information Society 5(1), 9-41.

Deibert, R., \& Rohozinski, R., 2008, 'Good for liberty, bad for security? Global civil society and the securitization of the Internet', in R. Deibert, J. Palfrey, R. Rohozinski \& J. Zittrain (eds.), Access denied: The practice and policy of global Internet filtering, pp. 123-150, The MIT Press, Cambridge.

Doyle, J., 2007, 'Picturing the clima(c)tic: Greenpeace and the representational politics of climate change communication', Science as Culture 16(2), 129-150. http://dx.doi.org/10.1080/09505430701368938

Dutta, S. \& Mia, I., 2011, The global information technology report 2010-2011, World Economic Forum, Geneva, Switzerland.

Dutta, S., Mia, I. \& Geiger, T. 2011. The global information technology report 20102011, World Economic Forum, Geneva, Switzerland.

ENISA, 2010, Online as soon as it happens, Author, Crete, Greece.

Facebook, 2013, Newsroom: Facebook's latest news, announcements and media resources, viewed 29 December 2012, from http://newsroom.fb.com/content/ default.aspx?NewsAreald $=22$

Freedom House, 2011, Freedom on the net 2011: A global assessment of internet and digital media, United Nations Democracy Fund, Washington, D.C.

Fuchs, C., 2008, Internet and society: Social theory in the information age, Routledge, New York.

Gapper, J., 2009, Technology is for revolution (and repression), viewed 27 July 2011 , from http://www.ft.com/intl/cms/s/0/4386d188-5cfe-11de-9d42-00144feabdc0. html\#axzz1qyLdo6BA

Garrett, K., 2006. 'Protest in an information society: A review of literature on social movements and new ICTs', Information, Communication and Society 9(9), 202224. http://dx.doi.org/10.1080/13691180600630773

Greenhill, R., 2011, The global information technology report 2010-2011, World Economic Forum, Geneva, Switzerland.
Greenpeace, 2006, McVictory: Victory as fast food giant pledges to help protect the Amazon, viewed 25 April 2013, from http://www.greenpeace.org/international/ en/news/features/McVictory-200706/

Greenpeace, 2010a, Nestlé - Kit-Kat, viewed 16 July 2013, from http://www.youtube. $\mathrm{com} /$ watch?feature $=$ endscreen\&NR $=1 \& \mathrm{v}=\mathrm{OEO}-\mathrm{-1R} \_\mathrm{d} 8 \mathrm{Y}$

Greenpeace, 2010b, Unfriend coal, viewed 19 May 2012m from http://www. greenpeace.org/usa/en/multimedia/videos/Facebook-Unfriend-Coal/

Habib, A., 2003, State-civil society relations in post-apartheid South Africa, paper presented at an Anthropology and Development Studies seminar, Rand Afrikaans University, Johannesburg.

Hara, N. \& Shachaf, P., 2008, 'Online peace movement organizations: A comparative analysis', in I. Chen \& T. Kidd (eds.), Social information technology: Connection society and cultural issues, pp. 52-67, Idea Group, Hershey. http://dx.doi org/10.4018/978-1-59904-774-4.ch004

Huffington, A., 2011, Lessons from Spain: 'Los Indignados,' Occupy Wall Street, and the failure of the status quo, viewed 27 July 2013, from http://www.huffingtonpost. com/arianna-huffington/spain-indignados-protests_b_1029640.html

International Telecommunications Union, 2009, Measuring the information society, Geneva, Switzerland.

Kinkade, S. \& Verclas, K.M., 2008, Wireless technologies for social change: Trends in mobile use by NGOs, UN Foundation-Vodaphone Group Foundation Partnership, Washington D.C./Berkshire.

Kreutzer, T., 2009, Generation mobile: Online and digital media usage on mobile phones among low-income urban youth in South Africa, University of Cape Town Center for Film and Media Studies, Cape Town.

Memmi, D., 2010, 'Sociology of virtual communities and social software design', in S. Murugesan (ed.), Web 2.0, 3.0, and X.0: Technologies, business, and socia applications, vol. 2, pp. 790-803, Information Science Reference, New York.

MobileActive, 2010, Nonprofit text messaging benchmarks, viewed March 2010, from http://www.slideshare.net/blueeyepathrec/nonprofit-text-messagingbenchmarks-study-2010-1

'Mobile marvels: A special report on telecoms in emerging markets', The Economist, 24 September, 2009, n.p.

NTEN, 2010, Nonprofit social network benchmark report, viewed 01 April 2011 , from http://www.nten.org/blog/2010/04/20/2010-nonprofit-social-networkbenchmark-report

NTEN, 2011a, 3rd annual nonprofit social network benchmark report, viewed 12 October 2011, from http://www.nonprofitsocialnetworksurvey.com/download. php

NTEN, 2011b, 2011 nonprofit communications trends report ... and what it all means for your good cause, viewed 01 November 2011, from http://www. nonprofitmarketingguide.com/resources/book/2011-nonprofit-communicationstrends/

Nugroho, Y., 2007, 'Does the Internet transform civil society? The case of civil society organisations in Indonesia', PhD thesis, Faculty of Humanities, University of Manchester.

Nugroho, Y. \& Tampubolon, G., 2008, 'Network dynamics in the transition to democracy: Mapping global networks of contemporary Indonesian civil society', Sociological Research Online 13(5).

Pew Research Center, 2011, Web 2.0, viewed 26 November 2012, from http://www. pewinternet.org/topics/Web-20.aspx

Ranchod, K., 2007, 'State-civil society relations in South Africa: Some lessons from engagement', Policy: Issues and Actors 20(7), 1-23.

Rigby, B., 2008, Mobilizing generation 2.0: A practical guide to using Web 2.0, JosseyBass, San Francisco.

Rogers, E.M., 2003, Diffusion of innovations, The Free Press, A division of Simon \& Schuster, New York.

SANGONeT, 2011, About SANGONeT, viewed 31 October 2011, from http://www. ngopulse.org/about.

Socialbakers, 2011, Heart of Social Media Statistics, viewed 28 December 2011, from http://www.socialbakers.com

Tandon, R., 2000, 'Riding high or nosediving: Development NGOs in the new millennium', Development in Practice 10(3/4), 319-329. http://dx.doi. millennium, Development in

UNICEF, 2011, What's your 'ASLR' to do you wanna go private, Author, New York.

Ushahidi, 2011, Ushahidi, viewed 29 September 2012, from http://www.ushahidi.com

Van de Donk, W., Loader, B., Nixon, P. \& Rucht, D., 2004,' Social movements and ICTs', in W. van de Donk, B. Loader, P. Nixon \& D. Rucht (eds.), Cyberprotest: New media, citizens and social movements, pp. 1-25, Routledge, London.

Wejnert, B., 2002, 'Integrating models of diffusion of innovations: A conceptual framework', Annual Review of Sociology 28, 297-326. http://dx.doi.org/10.1146/ annurev.soc.28.110601.141051

World Wide Worx, 2009, The state of ICTS in the South African NGO Sector, Johannesburg.

World Wide Worx, 2011, The South African social media landscape 2011, Author, Johannesburg.

Wu, M.C. \& Unhelkar, B., 2010, 'Mobile service orientated architecture (MSOA) for Business in the Web 2.0 era', in S. Murugesan (ed.), Web 2.0, 3.0, and X.O Technologies, business and social applications, vol. 1, pp. 178-191, Information Science Reference, New York.

Zakaria, F., 2011, 'The people vs. Putin', Time Magazine, 26 December, p. 32. 